\title{
Samoprocjena profesionalnih kompetencija studenata ranoga i predškolskog odgoja i obrazovanja u provođenju likovnih i glazbenih aktivnosti s djecom
}

Jerneja Herzog*

jerneja.herzog@um.si

Blaženka Bačlija Sušić***

blazenka.baclijasusic@ufzg.hr

Marijana Županić Benić***

marijana.zbenic@ufzg.hr https://doi.org/10.31192/np.16.3.10

UDK: 73/78:37.012-057.875

73/78:373.2-057.875

Prethodno priopćenje / Preliminary kommunication

Primljeno: 17. ožujka 2018.

Prihvaćeno: 11. svibnja 2018.

Likovna i glazbena umjetnost podržavaju emocionalni, kognitivni i psihomotorni razvoj u ranom djetinjstvu. Odgojitelji zato moraju imati dovoljne kompetencija da bi potaknuli sudjelovanje djece u umjetničkim aktivnostima pa je cilj ovog istraživanja bio ispitati kompetencije u umjetničkom području studenata u inicijalnom obrazovanju učitelja. U istraživanju su sudjelovali studenti treće godine ranog i predškolskog odgoja i obrazovanja Učiteljskog fakulteta, Sveučilišta u Zagrebu te Pedagoškog fakulteta, Sveučilišta u Mariboru. Ispitanici koji su završili gimnaziju su bolje procjenjivali svoje profesionalne kompetencije izvođenja glazbenih aktivnosti u odnosu na ispitanike koji su završili umjetničku srednju školu. Ispitanici koji su završili gimnaziju bolje su procjenjivali svoje kompetencije planiranja likovnih aktivnosti, ali ispitanici koji su završili srednju umjetničku školu bolje su procjenjivali svoje kompetencije izvođenja likovnih aktivnosti.

Ključne riječi: umjetnost, kompetencije učitelja, rani i predškolski odgoj i obrazovanje.

* Doc. dr. sc. Jerneja Herzog, Odsjek za likovnu umjetnost, Pedagoški fakultet, Sveučilište u Mariboru; Koroška cesta 160, SI-2000 Maribor.

*** Dr. sc. Blaženka Bačlija Sušić, Učiteljski fakultet, Sveučilište u Zagrebu, Savska 77, HR-10000 Zagreb.

***: Doc. dr. sc. Marijana Županić Benić, Učiteljski fakultet, Sveučilište u Zagrebu, Savska 77, HR10000 Zagreb. 


\section{Uvod}

Kompleksnost i zahtjevnost profesije odgojitelja, uz inicijalno obrazovanje, zahtijeva konstantno cjeloživotno učenje i stručno usavršavanje odgojitelja. Brojna istraživanja ukazuju na povezanost obrazovanja odgojitelja i kvalitete njegove odgojno-obrazovne prakse kao i povezanost kvalitete njegova rada $\mathrm{s}$ kasnijim dobrobitima u djetetovu razvoju. ${ }^{1} \mathrm{Uz}$ to, značajan čimbenik u razvoju kompetencija odgojitelja ima i kultura, kontekst, kao i društvene, političke i obrazovne intencije društva. ${ }^{2}$ Bez obzira na to što se danas kreativnost smatra jednom od najpoželjnijih osobina na tržištu rada, čest je slučaj da se umjetnost i umjetničke aktivnosti, kako u školama tako i u vrtićima, podređuju i smanjuju na račun temeljnih obrazovnih predmeta. To potvrđuje istraživanje koje ukazuje na to da aktivni odgojitelji imaju široko interdisciplinarno znanje koje bi trebalo dodatno produbiti specifičnim područjima kao što su matematika, znanjima iz informacijske i komunikacijske tehnologije (IKT) i prirodnih znanosti. ${ }^{3}$ Takva se stajališta sve više reflektiraju na obrazovne programe budućih odgojitelja te na kurikulume za rani i predškolski odgoj i obrazovanje. ${ }^{4}$

U skladu s time umjetničke se aktivnosti često zapostavljaju u odgojnoobrazovnoj praksi, pri čemu se kao tri temeljna razloga navode: nedostatak vremena za umjetničko obrazovanje, nesigurnost pripravnika pri sudjelovanju u umjetničkim aktivnostima i utjecaj njihovih prethodnih iskustava pri sudjelovanju u umjetničkim aktivnostima. ${ }^{5}$ Drugi identificiraju šest problema koji obeshrabruju učitelje/odgojitelje u provođenju umjetničkih aktivnosti: nedostatak osobnih vještina i znanja u umjetničkom području, nedostatak vremena i prioriteta, nedostatak sigurnosti, nedostatak sredstava i drugih aktivnosti

\footnotetext{
${ }^{1}$ Usp. Carrie LOBMAN, Sharon RYAN, Jill McLAUGHLIN, Reconstructing Teacher Education to Prepare Qualified Preschool Teachers. Lessons from New Jersey, Early Childhood Research and Practice, 7 (2005) 2, http://ecrp.uiuc.edu/v7n2/lobman.html (17.03.2018); Kathryn TOUT, Martha ZASLOW, Daniel BERRY, Quality and Qualifications. Links Between Professional Development and Quality in Early Care and Education Settings, u: Martha J. ZASLOW, Ivelisse MARTINEZ-BECK (ur.), Critical Issues in Early Childhood Professional Development, Baltimore, MD, Paul H. Brookes, Pub. Co., 2005, 77-110.

${ }^{2}$ Usp. MINISTRY OF EDUCATION AND SCIENCE, Curriculum for Preschool Lpfö 98. Revised 2010, Stockholm, Edita, 2011, http://www.ibe.unesco.org/curricula/sweden/sw_ppfw_2010_ eng.pdf (17.03.2018); Kathy SYLVA, Iram SIRAJ-BLATCHFORD, Brenda TAGGART, Pam SAMMONS, Edward MELHUISH, Karen ELLIOT, Vasiliki TOTSIKA, Capturing quality in early childhood through environmental rating scales, Early Childhood Research Quarterly, 21 (2006) 1, 76-92.

${ }^{3}$ Usp. Sonja SHERIDAN, Pia WILLIAMS, Anette SANDBERG, Tuula VUORINEN, Preschool teaching in Sweden. A profession in change, Educational Research, 53 (2011) 4, 415-437.

${ }^{4}$ Usp. Anna EHRLIN, Cecilia WALLERSTEDT, Preschool teachers' skills in teaching music. Two steps forward one step back, Early Child Development and Care, 184 (2014) 12, 18001811.

${ }^{5}$ Usp. Susanne GARVIS, Rowena Megan RIEK, Improving generalist teacher education in the arts, The Journal of the Arts in Society, 5 (2010) 3, 159-167.
} 
koje obavljaju. ${ }^{6}$ Recentni autori ističu važnost umjetničkih aktivnosti u ranom i predškolskom odgoju i obrazovanju jer potiču kod djece proces njihova emocionalnog razvoja, razvoj kreativnosti, višestrukih inteligencija, fine motorike, percepcije, samopouzdanja, motivacije, samoefikasnosti, socijalnih sposobnosti, empatije i raznih drugih sposobnosti.7 Sudjelovanje u umjetničkim aktivnostima potrebnim za razvoj navedenih sposobnosti kod djece u ranoj i predškolskoj dobi uvelike ovisi o podršci koju im pružaju roditelji, odgojitelji i vršnjaci. ${ }^{8}$ Međutim, odgojitelji i učitelji najviše utječu na poticanje i razvoj dječjeg stvaralaštva jer su odgovorni za vođenje umjetničkih aktivnosti u odgojno-obrazovnim ustanovama. Prema dosadašnjim istraživanjima mnogi se odgojitelji i učitelji neposredno nakon inicijalnog obrazovanja ne osjećaju kompetentnima za vođenje odgojno-obrazovnog procesa u umjetničkom području. ${ }^{9} \mathrm{U}$ području glazbene kulture brojna istraživanja pokazuju da se učitelji i odgojitelji ne osjećaju dovoljno kompetentnima u pjevanju i sviranju s djecom. ${ }^{10} \mathrm{U}$ području likovne kulture većina odgojitelja, njih $42 \%$, uopće ne provodi likovne aktivnosti u odgojno-obrazovnoj praksi, a njih čak $62 \%$ smatra se nedovoljno upoznatima s likovnim sadržajima koje mogu upotrijebiti u praksi. ${ }^{11}$ Odgojitelji, a i učitelji kao voditelji odgojno-obrazovnog procesa, često nisu sigurni u svoje

${ }^{6}$ Usp. Mary KEAR, Gloria CALLAWAY (ur.), Improving teaching and learning in the arts, London - New York, Falmer Press, 2000.

7 Usp. Ron BLEED, Visual Literacy in Higher Education, EDUCAUSE Learning Initiative Explorations, 1 (2005) 1-11; Susan HALLAM, The power of music. Its impact on the intellectual, social and personal development of children and young people, International Journal of $\mathrm{Mu}$ sic Education, 28 (2010) 3, 269-289; Kerry FREEDMAN, Social Perspectives on Art Education in the US. Teaching Visual Culture in a Democracy, Studies in Art Education, 41 (2000) 4, 314-329; Niklas PRAMLING, Susanne GARVIS, The Arts in Early Childhood Education, Oxford Index. Education (28.05.2013), http://dx.doi.org/10.1093/obo/9780199756810-0097 (17.03.2018).

${ }^{8}$ Usp. Sarah ROSE, Richard JOLLEY, Esther BURKITT, A Review of Children's, Teachers' and Parents' Influences on Children's Drawing Experience, International Journal of Art \& Design Education, 25 (2006) 3, 341-349.

9 Ann WELCH, The self-efficacy of primary teachers in art education, Issues in Educational Research, 5 (1995) 1, 71-84.

${ }^{10}$ Usp. Sarah HENNESSY, Overcoming the red-feeling. The development of confidence to teach music in primary school amongst student teachers, British Journal of Music Education, 17 (2000) 2, 183-196; Eve RUDDOCK, Samuel LEONG, 'I am unmusical!' The verdict of selfjudgement, International Journal of Music Education, 23 (2005) 1, 9-22; Deirdre RUSSELLBOWIE, What me? Teach music to my primary class? Challenges to teaching music in primary schools in five countries, Music Education Research, 11 (2009) 1, 23-36; Frederick SEDDON, Michele BIASUTTI, Non-music specialist trainee primary school teachers' confidence in teaching music in the classroom, Music Education Research, 10 (2008) 3, 403-421; Gillian STUNELL, Not musical? Identity Perceptions of Generalist Primary School Teachers in Relation to Classroom Music Teaching in England, Action, Criticism, and Theory for Music Education, 9 (2010) 2, 79-107; Susan YOUNG, Towards constructions of musical childhoods. Diversity and digital technologies, Early Child Development and Care, 179 (2009) 6, 695-705.

${ }^{11}$ Usp. Susanne GARVIS, Donna PENDERGAST, An Investigation of Early Childhood Teacher Self-Efficacy Beliefs in the Teaching of Arts Education, International Journal of Education \& the Arts, 12 (2011) 9, 1-16; https://eric.ed.gov/?id=EJ937070 (17.03.2018). 
sposobnosti vođenja likovnih aktivnosti na način da potaknu holistički razvoj djece. ${ }^{12}$ Ispitivanje odgojitelja ukazuje da im najviše nedostaje samopouzdanje i fleksibilnost u vođenju likovnih aktivnosti, što može biti posljedica nedostatka praktičnog rada tijekom inicijalnog, ali i cjeloživotnog obrazovanja. ${ }^{13}$

Kao glavni razlog zanemarivanja likovnog odgoja i obrazovanja u ranom i predškolskom odgoju uglavnom se spominje nedostatak samopouzdanja odgojitelja koje proizlazi iz negativne percepcije vlastite sposobnosti stvaralaštva i samoefikasnosti u kontekstu poučavanja likovne kulture. ${ }^{14} \mathrm{~S}$ obzirom da samoefikasnost označava uvjerenje osobe da može organizirati, usmjeravati i izvršavati radnje kojima uspješno ostvaruje zadanu aktivnost, ${ }^{15}$ dakako da subjektivna percepcija vlastite samoefikasnosti može utjecati na izvedbu stvaralačke aktivnosti. ${ }^{16}$

Ističe se važnost inicijalnog obrazovanja učitelja u njihovom osjećaju kompetentnosti za vodenje nastave likovne kulture u rezultatima longitudinalnog istraživanja provedenog među studentima budućim učiteljima o njihovim stavovima o likovnoj umjetnosti u obrazovanju te njihovoj samouvjerenosti u vlastite sposobnosti vođenja nastave likovne umjetnosti. ${ }^{17}$ Studenti nakon dvije godine inicijalnog obrazovanja, tijekom kojih pohađaju predmete vezane uz likovnu umjetnost, jasnije definiraju likovnu umjetnost i njezinu ulogu u razvoju djece. S obzirom na to da je likovna umjetnost važna u holističkom razvoju djece te da je samoefikasnost vođenja umjetničkih i umjetničko-stvaralačkih aktivnosti vezana uz specifične kontekste, programi za inicijalno obrazovanje odgojitelja moraju osigurati adekvatno praktično iskustvo budućim odgojiteljima i u vezi njihova vlastitog likovnog stvaralaštva i u vezi prakse poučavanja $u$ neposrednome radu s djecom. ${ }^{18}$

Uspješno provođenje kvalitetnog glazbenog programa u vrtićima uvelike ovisi o odgojiteljevom osjećaju osobne samo-efikasnosti u podučavanju glazbe, odnosno o njihovu osobnom uvjerenju u svoju sposobnost podučavanja glazbe i stvaranja pozitivnih ishoda s djecom u glazbi. Odgojitelji prilaze obrazovnim programima s utvrđenim stajalištima, uvjerenjima, vrijednostima i vlastitim osjećajem samopouzdanja u podučavanju. ${ }^{19}$ Pokazalo se da nedostatak pripremljenosti stvara negativna stajališta prema glazbi kod represivnih odgojitelja

\footnotetext{
${ }^{12}$ Usp. Angela ANNING, Conversations Around Young Children's Drawing. The Impact of the Beliefs of Significant Others at Home and School, International Journal of Art E Design Education, 21 (2002) 3, 197-208; Rose, Jolley, Burkitt, nav. dj.

${ }^{13}$ Usp. Rose, Jolley, Burkitt, nav. dj.

${ }^{14}$ Usp. Welch, nav. dj.; Garvis, Pendergast, nav. dj.

${ }^{15}$ Usp. Albert BANDURA, Self-efficacy. Toward a unifying theory of behavioral change, Psychological Review, 84 (1977) 2, 191-215.

${ }^{16}$ Usp. Garvis, Pendergast, nav. dj.

${ }^{17}$ Usp. Robyn GIBSON, Learning to be an Art Educator. Student Teachers' Attitudes to Art and Art education, International Journal of Art E Design Education, 22 (2003) 1, 111-120.

${ }^{18}$ Usp. Ji-Hi BAE, Learning to Teach Visual Arts in an Early Childhood Classroom. The Teacher's Role as a Guide, Early Childhood Education Journal, 31 (2004) 4, 247-254; Gibson, nav. dj.

${ }^{19}$ Usp. Jennifer VANNATTA-HALL, Music education in early childhood teacher education. The impact of a methods course on pre-service teachers perceived confidence and competence to
} 
i nedostatak samopouzdanja u njihovoj sposobnosti podučavanja glazbe..$^{20}$ Posljedica toga je izbjegavanje provođenja glazbenih aktivnosti ili njihovo neučinkovito provođenje.

Utvrđeno je da na samopouzdanje mogu utjecati brojni čimbenici pa istraživači nastoje istražiti kako oni doprinose sveobuhvatnom postignuću u podučavanju glazbe. Glazbena vještina ili prosudba odgojitelja o vlastitim glazbenim vještinama može utjecati na njihovo samopouzdanje, ${ }^{21}$ dok negativna percepcija može biti rezultat njihovih prethodnih iskustava u glazbenom obrazovanju. Istraživanjem je utvrđeno da takva negativna percepcija može biti povezana $\mathrm{s}$ neuspješnim pokušajem stvaranja glazbe $u$ prošlosti ili nedostatkom razumijevanja glazbe ili sposobnosti sviranja instrumenta. ${ }^{22}$ Problem može biti i nedostatak samopouzdanja kod učitelja koji nemaju glazbenu edukaciju te stoga postoji potreba za njihovim trajnim profesionalnim razvojem ili boljim temeljnim obrazovanjem radi razvoja specifičnih glazbenih vještina i glazbenog jezika. Razina samopouzdanja povezana je s kompetencijom i samoefikasnošću u polju glazbene edukacije, pri čemu se ističe da je »sigurnost beznačajna ukoliko nije popraćena adekvatnim kompetencijama «, ${ }^{23}$ dok nedostatak samouvjerenosti u provođenju nekih glazbenih aktivnosti može proizlaziti iz činjenice da su odgojitelji svjesni svojih nedostatnih glazbenih kompetencija. ${ }^{24}$

Pojam »kompetencije « u ovom radu odnosi se na kombinaciju znanja, vještina i sposobnosti koje studenti odgojiteljskog studija stječu tijekom svojega inicijalnog obrazovanja, kao i njihove praktične primjene u okviru odgojno-obrazovne prakse. U okviru umjetničkog obrazovanja područja likovne i glazbene umjetnosti važan su aspekt djetetova cjelovita razvoja od njegove rane dobi jer utječu na djetetov emocionalni, kognitivni, socijalni i psihomotorni razvoj. Da bi odgojitelji bili adekvatna podrška i poticatelji pri djetetovu umjetničkom izrazu, potrebna je stanovita razina njihovih umjetničkih vještina, znanja i sposobnosti. Stoga je svrha ovoga rada bila istražiti profesionalne kompetencije studenata s obzirom na područje likovne i glazbene kulture.

teach music (neobjavljena doktorska disertacija), Champagne, IL, University of Illinois at Urbana-Champagne, 2010.

${ }^{20}$ Usp. Nancy H. BARRY, Music and education in the elementary music methods class, Journal of Music Teacher Education, 2 (1992) 1, 16-23; Edward GIFFORD, The Musical Training of Primary Teachers: Old Problems, New Insights and Possible Solutions, British Journal of Music Education, 10 (1993) 1, 33-46; Neryl JEANNERET, Model for Developing Preservice Primary Teachers' Confidence to Teach Music, Bulletin of the Council for Research in Music Education, 133 (1997) 37-44; Janet MILLS, The Generalist Primary Teacher of Music. A Problem of Confidence, British Journal of Music Education, 6 (1989) 2, 125-138; Seddon, Biasutti, nav. dj.

${ }^{21}$ Usp. Rosamund SHUTER-DYSON, Musical Ability, The Psychology of Music, 2 (1999) 627651.

${ }^{22}$ Usp. Ruddock, Leong, nav. dj.

${ }^{23}$ Usp. Robert A. WIGGINS, Jackie WIGGINS, Primary Music Education in the Absence of Specialists, International Journal of Education \& the Arts, 9 (2008) 12, 1-27, 3.

${ }^{24}$ Usp. Miomira ĐURĐANOVIĆ, Irena STOŠIĆ, Preschool teachers and their levels of interest in developing musical competencies, Facta Universitatis, Series. Visual Arts and Music, 3 (2017) 1, 15-27. 


\section{Svrha istraživanja}

Svrha istraživanja bila je analizirati samoprocjenu profesionalnih kompetencija u umjetničkom području (likovnom i glazbenom) kod studenata treće godine studijskog programa Rani i predškolski odgoj i obrazovanje. Željeli smo analizirati samoprocjenu profesionalnih kompetencija u umjetničkom području kod studenata s aspekta stečenog srednjoškolskog obrazovanja (gimnazija, srednja strukovna škola, umjetnička srednja škola).

\section{Metodologija}

\subsection{Metoda istraživanja i istraživački uzorak}

Kvantitativno istraživanje koristilo je opisnu metodu i kauzalno-eksperimentalnu metodu. Provedeno je na prigodnom uzorku treće godine studijskoga programa Rani i predškolski odgoj i obrazovanje (RPOO) na Pedagoškom fakultetu Sveučilišta u Mariboru i Učiteljskom fakultetu Sveučilišta u Zagrebu $(\mathrm{N}=154)$. Odabran je namjerni uzorak jer su studenti treće godine završili s vježbama iz Metodike likovne i glazbene kulture te imaju iskustvo provođenja likovnih i glazbenih aktivnosti s djecom vrtićke dobi. U istraživanju je sudjelovao $61(39,6 \%)$ slovenski student i $93(60,4 \%)$ hrvatska studenta.

\subsection{Postupci prikupljanja podataka i instrument}

Za potrebe ovog istraživanja kreiran je anonimni anketni upitnik za prikupljanje podataka o obilježjima ispitanika i samoprocjeni profesionalnih kompetencija kod provođenja likovnih i glazbenih aktivnosti. Anketni upitnik ponuđen je studentima obaju fakulteta uključenih u istraživanje. Pored općih podataka, upitnik je sadržavao 50 pitanja na kojima su studenti procijenili razinu slaganja pomoću Likertove ljestvice od 5 stupnjeva: 1 - nikada, 2 - rijetko, 3 - ponekad, 4 - često, 5 - redovito. Pitanja su bila formirana u četiri kompozitne varijable s pripadajućim pojedinačnim varijablama, od kojih su dvije vezane uz glazbeno područje, a dvije uz područje likovnih umjetnosti.

\subsection{Hipoteze}

U istraživanju nas je zanimalo koliko utječe vrsta srednjoškolskog obrazovanja na samoprocjenu profesionalnih kompetencija studenata predškolskog odgoja u umjetničkom području. 
Pretpostavili smo da je srednja škola koju su ispitanici pohađali prije upisa na fakultet značajan čimbenik pri samoprocjeni njihovih kompetencija iz područja likovne i glazbene umjetnosti. Tako smo pretpostavili da studenti koji su pohađali umjetničke srednje škole bolje samoprocjenjuju svoje profesionalne kompetencije u području likovne i glazbene kulture.

H1: Postoji statistički značajna razlika kod samoprocjene kompetencija vezanih uz glazbene aktivnosti kod studenata koji su pohađali umjetničku srednju školu.

H2: Postoji statistički značajna razlika kod samoprocjene kompetencija vezanih uz likovne aktivnosti kod studenata koji su pohađali umjetničku srednju školu.

H3: Postoji statistički značajna razlika kod samoprocjene kompetencija vezanih uz glazbeno-stvaralačke aktivnosti kod studenata koji su pohađali umjetničku srednju školu.

H4: Postoji statistički značajna razlika kod samoprocjene kompetencija vezanih uz likovno-stvaralačke aktivnosti kod studenata koji su pohađali umjetničku srednju školu.

\subsection{Postupci obrade podataka}

Prikupljeni podaci statistički su obrađeni korištenjem SPSS programa, a obrađeni su metodama deskriptivne i inferencijalne statistike. U obradi podataka upotrijebljene su sljedeće metode: distribucija frekvencije (f, \%) karakteristika sudionika; deskriptivna statistika (srednja vrijednost - standardna devijacija); Kruskal-Wallis neparametrijski test

\section{Rezultati i rasprava}

U tablici 1 su rezultati vezani uz samoprocjenu studenata kod promatranja kompetencija vezanih za provođenje glazbenih aktivnosti u odgojno-obrazovnom procesu.

Analiza rezultata pokazuje da postoji statistički značajna razlika u korist studenata koji su prije upisa na fakultet pohađali gimnaziju i to pri samoprocjeni sljedećih kompetencija: upoznavanje, usvajanje i ponavljanje brojalice $(\mathrm{P}=0,042)$, kompetencija vezanih uz provođenje dječjih igara s pjevanjem $(\mathrm{P}=0,006)$ te kompetencija vezanih uz aktivnost sviranja na samostalno izrađenim zvečkama ili glazbalima dječjeg instrumentarija $(\mathrm{P}=0,044)$. S obzirom na dobivene rezultate pojedinačnih varijabli hipoteza $\mathrm{H} 1$ nije potvrđena. Navedene rezultate možemo tumačiti ovako: bez obzira što srednja umjetnička škola, primjerice srednja glazbena škola, pruža određena glazbena znanja i vještine (znanja iz glazbene teorije, solfeggia, sviranje instrumenta, znanja iz povijesti 
Tablica 1. Rezultati usporedbe samoprocjene kompetencija vezanih uz provođenje glazbenih aktivnosti u odgojno-obrazovnom procesu ovisno o vrsti srednje škole koju su pohađali studenti prije upisa na fakultet.

\begin{tabular}{|c|c|c|c|c|c|}
\hline \multirow{2}{*}{$\begin{array}{l}\text { Kompetencije provođenja glazbenih } \\
\text { aktivnosti }\end{array}$} & \multirow{2}{*}{$\begin{array}{c}\text { Srednja } \\
\text { škola }\end{array}$} & \multirow{2}{*}{$\mathbf{N}$} & \multirow{2}{*}{$\mathbf{R}$} & \multicolumn{2}{|c|}{ K-W test } \\
\hline & & & & $\mathbf{H}$ & $\mathbf{p}$ \\
\hline \multirow{3}{*}{ Upoznavanje, usvajanje i ponavljanje pjesme } & GIM & 62 & 84,51 & \multirow{3}{*}{3,735} & \multirow{3}{*}{0,154} \\
\hline & SSŠ & 89 & 72,25 & & \\
\hline & UMSŠ & 2 & 55,50 & & \\
\hline \multirow{3}{*}{ Upoznavanje, usvajanje i ponavljanje brojalice } & GIM & 62 & 86,86 & \multirow{3}{*}{6,333} & \multirow{3}{*}{0,042} \\
\hline & SSŠ & 89 & 70,71 & & \\
\hline & UMSŠ & 2 & 51,75 & & \\
\hline \multirow{3}{*}{ Dječje igre s pjevanjem } & GIM & 62 & 89,86 & \multirow{3}{*}{10,128} & \multirow{3}{*}{0,006} \\
\hline & SSŠ & 89 & 67,71 & & \\
\hline & UMSŠ & 2 & 67,75 & & \\
\hline \multirow{3}{*}{$\begin{array}{l}\text { Sviranje na samostalno izrađenim zvečkama ili } \\
\text { glazbalima dječjeg instrumentarija }\end{array}$} & GIM & 62 & 86,97 & \multirow{3}{*}{6,248} & \multirow{3}{*}{0,044} \\
\hline & SSŠ & 89 & 70,63 & & \\
\hline & UMSŠ & 2 & 51,25 & & \\
\hline \multirow{3}{*}{ Aktivno slušanje glazbe } & GIM & 62 & 83,02 & \multirow{3}{*}{2,211} & \multirow{3}{*}{0,331} \\
\hline & SSŠ & 89 & 73,04 & & \\
\hline & UMSŠ & 2 & 66,78 & & \\
\hline \multirow{3}{*}{ Glazbeno stvaralaštvo } & GIM & 62 & 79,16 & \multirow{3}{*}{0,856} & \multirow{3}{*}{0,652} \\
\hline & SSŠ & 89 & 75,15 & & \\
\hline & UMSŠ & 2 & 55,50 & & \\
\hline
\end{tabular}

Legenda: GIM = gimnazija, SSŠ = srednja strukovna škola, UMSŠ = umjetnička srednja škola, $\mathrm{R}=$ prosjek rangova, $\mathrm{K}-\mathrm{W}$ test $=$ Kruskal-Wallisov test .

glazbe, harmonije, polifonije i dr.), gimnazijski program daje učenicima puno veću širinu u znanjima iz različitih područja u odnosu na program srednje umjetničke glazbene škole. Studenti koji su završili srednju umjetničku školu previše su usmjereni reproduktivnim aktivnostima u kojima sve više prevladava kompetitivni duh (osobito u glazbenoj naobrazbi), dok su studenti koji su završili gimnazijski program puno manje opterećeni ishodom svojih glazbenih aktivnosti te se osjećaju kompetentnijima u njihovu provođenju na temelju znanja stečenog u okviru općeg obrazovanja. Dobivene rezultate dakle možemo pripisati širini znanja iz različitih područja koje se stječe gimnazijskim programom. Širina znanja puno je važnija od dubine te je previše poznavanja neke materije zapravo hendikep. Kroz širinu znanja koristi se više inspiracije što onda potiče čovjeka na istraživanje neobičnih pristupa. ${ }^{25}$ Kao i u pogledu glazbenih aktivnosti, istražili smo i samoprocjenu kompetencija studenata obaju fakulteta u području likovnih umjetnosti u odgojno-obrazovnom procesu. U okviru obavljanja umjetničkih aktivnosti uključili smo dvanaest kompetencija koje je student trebao usvojiti tijekom svog inicijalnog obrazovanja.

\footnotetext{
${ }^{25}$ Usp. Dave BIRSS, A User Guide to the Creative Mind, Morrisville, NC, Lulu Press, 2013.
} 
Tablica 2. Rezultati usporedbe samoprocjene kompetencija vezanih uz provođenje likovnih aktivnosti u odgojno-obrazovnom procesu ovisno o vrsti srednje škole koju su pohađali studenti prije upisa na fakultet.

\begin{tabular}{|c|c|c|c|c|c|}
\hline \multirow{2}{*}{ Kompetencije provođenja likovnih aktivnosti } & \multirow{2}{*}{$\begin{array}{c}\text { Srednja } \\
\text { škola }\end{array}$} & \multirow{2}{*}{$\mathbf{N}$} & \multirow{2}{*}{$\mathbf{R}$} & \multicolumn{2}{|c|}{$\mathrm{K}-\mathrm{W}$ test } \\
\hline & & & & $\mathrm{H}$ & $\mathbf{p}$ \\
\hline \multirow{3}{*}{ Crtanje različitim crtačkim tehnikama } & GIM & 62 & 82,27 & \multirow{3}{*}{1,835} & \multirow{3}{*}{0,399} \\
\hline & SSŠ & 89 & 73,27 & & \\
\hline & UMSŠ & 2 & 79,75 & & \\
\hline \multirow{3}{*}{ Slikanje različitim slikarskim tehnikama } & GIM & 62 & 83,98 & \multirow{3}{*}{3,090} & \multirow{3}{*}{0,213} \\
\hline & SSS̆ & 89 & 72,08 & & \\
\hline & UMSŠ & 2 & 72,25 & & \\
\hline \multirow{3}{*}{$\begin{array}{l}\text { Oblikovanje skulpture i korišstenje različitih } \\
\text { kiparskih tehnika }\end{array}$} & GIM & 62 & 87,15 & \multirow{3}{*}{8,589} & \multirow{3}{*}{0,014} \\
\hline & SSŠ & 89 & 68,53 & & \\
\hline & UMSŠ & 2 & 100,50 & & \\
\hline \multirow{3}{*}{ Grafika, otisak } & GIM & 62 & 88,09 & \multirow{3}{*}{11,514} & \multirow{3}{*}{0,003} \\
\hline & SSŠ & 89 & 68,11 & & \\
\hline & UMSŠ & 2 & 129,00 & & \\
\hline \multirow{3}{*}{$\begin{array}{l}\text { Upoznavanje područja primijenjene umjetnosti } \\
\text { i dizajna }\end{array}$} & GIM & 62 & 81,88 & \multirow{3}{*}{1,688} & \multirow{3}{*}{0,430} \\
\hline & SSŠ & 89 & 73,35 & & \\
\hline & UMSŠ & 2 & 88,00 & & \\
\hline \multirow{3}{*}{ Oblikovanje lutaka } & GIM & 62 & 80,90 & \multirow{3}{*}{0,908} & \multirow{3}{*}{0,635} \\
\hline & SSŠ & 89 & 74,41 & & \\
\hline & UMSŠ & 2 & 71,25 & & \\
\hline \multirow{3}{*}{ Izrada scenografije } & GIM & 62 & 82,10 & \multirow{3}{*}{1,504} & \multirow{3}{*}{0,471} \\
\hline & SSŠ & 89 & 73,59 & & \\
\hline & UMSŠ & 2 & 70,75 & & \\
\hline \multirow{3}{*}{ Građenje i arhitektonske tehnike } & GIM & 62 & 83,37 & & \\
\hline & SSŠ & 89 & 72,52 & 2,397 & 0,302 \\
\hline & UMSŠ & 2 & 78,75 & & \\
\hline & GIM & 62 & 79,25 & & \\
\hline $\begin{array}{l}\text { Novi mediji (strip, animirani film, kompjutorska } \\
\text { orafika) }\end{array}$ & SSŠ & 89 & 75,38 & 0,307 & 0,858 \\
\hline & UMSŠ & 2 & 79,50 & & \\
\hline & GIM & 62 & 79,31 & & \\
\hline Izrada slikovnica & SSŠ & 89 & 75,37 & 0,316 & 0,854 \\
\hline & UMSŠ & 2 & 77,75 & & \\
\hline & GIM & 62 & 78,12 & & \\
\hline Promatranje i analiza umjetničkog djela & SSŠ & 89 & 74,34 & 0,423 & 0,810 \\
\hline & UMSŠ & 2 & 86,50 & & \\
\hline & GIM & 62 & 74,73 & & \\
\hline Likovno-metodičke igre & SSŠ & 89 & 76,78 & 0,104 & 0,949 \\
\hline & UMSŠ & 2 & 79,75 & & \\
\hline
\end{tabular}

LEGENDA: GIM = gimnazija, SSŠ = srednja strukovna škola, UMSŠ = umjetnička srednja škola, $\mathrm{R}$ = prosjek rangova, $\mathrm{K}-\mathrm{W}$ test $=$ Kruskal-Wallisov test. 
Prema prikazanim rezultatima vidimo da se studenti slično procjenjuju u kompetencijama vezanim uz provođenje likovnih aktivnosti u pedagoškom radu, osim u kompetencijama vezanim uz oblikovanje skulpture i korištenje različitih kiparskih tehnika i grafičkih i tiskarskih aktivnosti, u kojima su studenti koji su pohađali umjetničku srednju školu bolje procijenili vlastite sposobnosti $(\mathrm{P}=0,014)$ i $(\mathrm{P}=0,003)$. Navedenim rezultatima možemo djelomično potvrditi hipotezu H2. Dobivene rezultate možemo protumačiti time da se u umjetničkim srednjim školama više prakticira likovno stvaranje vezano u sva likovna područja (iz kojih smo i mi formirali pojedinačne varijable koje opisuju kompetencije te smo očekivali veći broj statistički značajnih razlika kod studenata koji su pohađali umjetničku srednju školu). Možemo reći da je jako važno u periodu studija studente motivirati za (likovno) umjetničko izražavanje tako da to na njih djeluje poticajno i da ih se upozna sa svim likovnim područjima te likovnim tehnikama da bi ih mogli implementirati u svojoj budućoj profesionalnoj praksi. Osim navedenog, od izuzetne je važnosti da se djetetu omogući izražavanje kroz razne grane umjetnosti čime se potiče razvoj kognitivnih, afektivnih i psihomotornih područja djeteta, odnosno njegov holistički razvoj. ${ }^{26}$ O odgajatelju ovisi hoće li djeca u procesu umjetničkih kreativnih aktivnosti razviti svoje potencijale do maksimuma; hoće li oni pritom razviti nove vještine kroz različite metode i oblike učenja; i hoće li znati kako promatrati, tumačiti, percipirati i time razviti svoje sposobnosti. ${ }^{27}$

U istraživanju nas je zanimalo kako studenti koji su završili različite programe srednjoškolske naobrazbe procjenjuju vlastite glazbeno-stvaralačke kompetencije. Statistički značajna razlika dobivena je u korist studenata koji su pohađali srednju umjetničku školu pri aktivnosti slušanja i oponašanja te prepoznavanja zvukova $-\mathrm{P}=0,023$ i tjeloglazba - body-percussion $-\mathrm{P}=0,000$. Kod aktivnosti variranje melodije, ritma, tempa, dinamike i/ili karaktera u poznatoj pjesmi ili brojalici $(\mathrm{P}=0,000)$ te aktivnosti slušanja glazbe uz ples $\mathrm{i} / \mathrm{ili}$ likovno izražavanje $(\mathrm{P}=0,046)$, statistički značajna razlika dobivena je u korist studenata koji su pohađali gimnaziju.

Dobivene rezultate možemo tumačiti činjenicom da su studenti koji su pohađali srednju umjetničku školu (glazbenu, plesnu i sl.) više senzibilizirani na zvuk i glazbu koja čini dio njihovih svakodnevnih aktivnosti. Stoga se osjećaju kompetentnijim za provođenje aktivnosti vezanih uz senzibilizaciju na zvuk te aktivnosti tjeloglazbe (body-percussion). S druge strane, dobivena je statistički značajna razlika pri samoprocjeni aktivnosti vezanih uz aktivnosti variranja melodije, ritma, tempa, dinamike i/ili karaktera u poznatoj pjesmi ili brojalici

\footnotetext{
${ }^{26}$ Usp. Antonija BALIĆ-ŠIMRAK, Iva ŠVERKO, Marijana ŽUPANIĆ BENIĆ, U prilog holističkom pristupu kurikulumu likovne kulture, u: Danijel ŽABČIĆ i dr. (ur.), Umjetničko djelo u likovnom odgoju i obrazovanju, zbornik radova ECNSI 2009.-2011., Zagreb, Učiteljski fakultet, 2010, 51-61.

${ }^{27}$ Usp. Matjaž DUH, Tomaž ZUPANČIĆ, The communicative possibilities of contemporary art within the frame of art education, Informatologia, 42 (2009) 3, 180-185.
} 
Tablica 3. Rezultati usporedbe samoprocjene kompetencija vezanih uz provođenje glazbeno-stvaralačkih aktivnosti u odgojno-obrazovnom procesu ovisno o vrsti srednje škole koju su pohađali studenti prije upisa na fakultet.

\begin{tabular}{|c|c|c|c|c|c|}
\hline \multirow{2}{*}{$\begin{array}{l}\text { Kompetencije provođenja glazbeno- } \\
\text { stvaralačkih aktivnosti }\end{array}$} & \multirow{2}{*}{$\begin{array}{l}\text { Srednja } \\
\text { škola }\end{array}$} & \multirow{2}{*}{$\mathbf{N}$} & \multirow{2}{*}{$\mathbf{R}$} & \multicolumn{2}{|c|}{ K-W test } \\
\hline & & & & $\mathbf{H}$ & $\mathbf{p}$ \\
\hline \multirow{3}{*}{$\begin{array}{l}\text { Aktivnosti vezane uz osluškivanje i oponašanje } \\
\text { te prepoznavanje zvukova }\end{array}$} & GIM & 62 & 82,80 & \multirow{3}{*}{7,577} & \multirow{3}{*}{0,023} \\
\hline & SSŠ & 89 & 70,79 & & \\
\hline & UMSŠ & 2 & 132,50 & & \\
\hline \multirow{3}{*}{ Tjeloglazba - body-percussion } & GIM & 62 & 92,47 & \multirow{3}{*}{19,878} & \multirow{3}{*}{0,000} \\
\hline & SSŠ & 89 & 64,30 & & \\
\hline & UMSŠ & 2 & 132,25 & & \\
\hline \multirow{3}{*}{$\begin{array}{l}\text { Pjevani govor, postavljanje glazbenih pitanja i } \\
\text { završavanje nedovršenih glazbenih fraza }\end{array}$} & GIM & 62 & 79,57 & \multirow{3}{*}{1,084} & \multirow{3}{*}{0,582} \\
\hline & SSŠ & 89 & 73,96 & & \\
\hline & UMSŠ & 2 & 95,75 & & \\
\hline \multirow{3}{*}{ Ritmizirani govor } & GIM & 62 & 85,48 & \multirow{3}{*}{4,802} & \multirow{3}{*}{0,088} \\
\hline & SSŠ & 89 & 70,79 & & \\
\hline & UMSŠ & 2 & 57,00 & & \\
\hline \multirow{3}{*}{$\begin{array}{l}\text { Variranje melodije, ritma, tempa, dinamike i/ili } \\
\text { karaktera u poznatoj pjesmi ili brojalici }\end{array}$} & GIM & 62 & 94,11 & \multirow{3}{*}{16,619} & \multirow{3}{*}{0,000} \\
\hline & SSŠ & 89 & 63,90 & & \\
\hline & UMSŠ & 2 & 100,0 & & \\
\hline \multirow{3}{*}{ Improviziranje/komponiranje riječi i melodije } & GIM & 62 & 80,93 & \multirow{3}{*}{1,163} & \multirow{3}{*}{0,559} \\
\hline & SSŠ & 89 & 73,49 & & \\
\hline & UMSŠ & 2 & 75,00 & & \\
\hline \multirow{3}{*}{$\begin{array}{l}\text { Aktivnosti vezane uz sviranje na samostalno } \\
\text { izrađenim zvečkama ili glazbalima dječjeg } \\
\text { instrumentarija - tzv. aktivnost »Mali orkestar« }\end{array}$} & GIM & 62 & 80,76 & \multirow{3}{*}{5,062} & \multirow{3}{*}{0,080} \\
\hline & SSŠ & 89 & 74,96 & & \\
\hline & UMSŠ & 2 & 15,00 & & \\
\hline \multirow{3}{*}{$\begin{array}{l}\text { Aktivnosti vezane uz poticanje djece na } \\
\text { ozvučivanje priče ili pjesme tijekom njihovog } \\
\text { izvođenja (oponašanje glasom ili instrumentom } \\
\text { i sl.) }\end{array}$} & GIM & 62 & 82,93 & \multirow{3}{*}{3,667} & \multirow{3}{*}{0,160} \\
\hline & SSŠ & 89 & 72,91 & & \\
\hline & UMSŠ & 2 & 40,25 & & \\
\hline \multirow{3}{*}{ Uglazbljivanje stihova } & GIM & 62 & 73,70 & & \\
\hline & SSŠ & 89 & 79,12 & 1,701 & 0,427 \\
\hline & UMSŠ & 2 & 45,50 & & \\
\hline & GIM & 62 & 86,56 & & \\
\hline Slušanje glazbe uz ples i/ili likovno izražavanje & SSŠ & 89 & 69,40 & 6,176 & 0,046 \\
\hline & UMSŠ & 2 & 85,50 & & \\
\hline
\end{tabular}

LEGENDA: GIM = gimnazija, SSŠ = srednja strukovna škola, UMSŠ = umjetnička srednja škola, $\mathrm{R}$ = prosjek rangova, $\mathrm{K}-\mathrm{W}$ test $=$ Kruskal-Wallisov test.

te aktivnosti slušanja glazbe uz ples i/ili likovno izražavanje u korist studenata koji su završili gimnazijski srednjoškolski program. U okviru gimnazijskog programa predmeta glazbene kulture, učenici se također susreću s aktivnim slušanjem glazbe, pri čemu je glazbeni doživljaj temelj glazbene spoznaje, a 
glazba djeluje na sva naša emocionalna, fiziološka i intelektualna osjetila. ${ }^{28} \mathrm{Uz}$ to na prepoznavanje zvuka utječu iskustva, okolina te vrijednosti šire kulture. ${ }^{29}$

Dobiveni rezultati nadalje ukazuju na statistički značajnu razliku u korist studenata koji su pohađali gimnaziju pri aktivnostima ritmiziranog govora $(\mathrm{P}=$ $0,088)$ te aktivnostima sviranja na samostalno izrađenim zvečkama ili glazbalima dječjeg instrumentarija - tzv. aktivnost »Mali orkestar« $(\mathrm{P}=0,080)$. Polazeći od stajališta da glazbu treba učiti na aktivan i kreativan način Carl Orff je isticao:

»Elementarna glazba nije nikada sama glazba, nego forme u kojima su s glazbom ujedinjeni i pokret, ples i govor. To je glazba koju netko sam stvara, u kojoj nismo slušatelji, nego sudjelujemo u njoj.« ${ }^{30}$

Smisao Orffova glazbeno-pedagoškog koncepta upravo je to da svatko može biti aktivan stvaratelj glazbe, a ne samo pasivan konzument. $S$ obzirom da se studenti koji nisu pohađali srednju umjetničku školu ne osjećaju kompetentnim u sviranju nekog glazbenog instrumenta, poput studenata koji su primjerice pohađali srednju glazbenu školu, oni imaju tendenciju bolje samoprocjene svojih glazbenih sposobnosti sviranja na Orffovu instrumentariju kao i ritmiziranog govora koji je sastavni dio ovoga glazbeno-pedagoškog koncepta.

Rezultati u tablici 4 prikazuju kompetencije koje formiraju niz umjetničkih kreativnih aktivnosti i uočena je statistički značajna razlika kod dvije pojedinačne varijable (planiranje i provođenje likovno-stvaralačkih aktivnosti na takav način da se usmjerava djetetov opažaj na neki oblik ili pojavu, postavljanjem pitanja $\mathrm{P}=0,004$ i poticanje interesa i likovnog izražavanja kroz razgovor o nečemu što su djeca spontano vidjela i doživjela prije kraćeg ili duljeg vremena $\mathrm{P}=0,031)$. U oba primjera uočena je statistički značajna razlika u korist studenata koji su pohađali gimnaziju. Kod kompetencija igre s likovnim materijalom nije uočena statistički značajna razlika ovisna o srednjoj školi koju su ispitanici pohađali $(\mathrm{P}=0,064)$. A statistički značajna razlika $(\mathrm{P} 0,087)$ kod kompetencija izvođenja projekta likovnog stvaralaštva (dublje pristupanje temi) koji traju duže vremensko razdoblje postoji u korist studenata koji su pohađali srednju umjetničku školu. Navedeni rezultati djelomično potvrđuju hipotezu H4.

Dobiveni rezultati važan su pokazatelj u kojim se propitanim segmentima studenti osjećaju kompetentnijima, odnosno koje od navedenih kompetencija smatraju više ili manje razvijenima. Uočava se neposredan rezultat inicijalnog obrazovanja na razvijanje osjećaja kompetentnosti kod studenata za vođenje likovno-stvaralačkih aktivnosti, što u svom istraživanju ističu i Gibson i Bae, naime da se taj osjećaj razvija s većim iskustvom studenata kod sudjelovanja u aktivnostima u neposrednom radu s djecom. ${ }^{31}$

\footnotetext{
${ }^{28}$ Usp. Renata SAM PALMIĆ, Glazbeni doživljaj u odgoju djeteta, Rijeka, Glosa, 1998.

${ }^{29}$ Usp. Leopoldina PLUT PREGELJ, Poslušanje. Način življenja in vir znanja, Ljubljana, DZS, 2012.

${ }^{30}$ Usp. Carl ORFF, Orff-Schulwerk - Past and Future, u: I. CARLEY (ur.), Orff Reechoes, USA. American Orff-Schulwerk Association, 1963, 3-13, 4.

${ }^{31}$ Usp. Bae, nav. dj.; Gibson, nav. dj.
} 
Tablica 4. Rezultati usporedbe samoprocjene kompetencija vezanih uz provođenje likovno-stvaralačkih aktivnosti u odgojno-obrazovnom procesu ovisno o vrsti srednje škole koju su pohađali studenti prije upisa na fakultet.

\begin{tabular}{|c|c|c|c|c|c|}
\hline \multirow{2}{*}{$\begin{array}{l}\text { Kompetencije provođenja likovno- } \\
\text { stvaralačkih aktivnosti }\end{array}$} & \multirow{2}{*}{$\begin{array}{l}\text { Srednja } \\
\text { škola }\end{array}$} & \multirow{2}{*}{$\mathbf{N}$} & \multirow{2}{*}{$\mathbf{R}$} & \multicolumn{2}{|c|}{ K-W test } \\
\hline & & & & $\mathrm{H}$ & p \\
\hline \multirow{3}{*}{$\begin{array}{l}\text { Planiranje i provođenje aktivnosti koje } \\
\text { usmjeravaju djetetov opažaj na neki oblik ili } \\
\text { pojavu, postavljanjem pitanja. }\end{array}$} & GIM & 62 & 89,77 & \multirow{3}{*}{11,155} & \multirow{3}{*}{0,004} \\
\hline & SSŠ & 89 & 67,13 & & \\
\hline & UMSŠ & 2 & 88,50 & & \\
\hline \multirow{3}{*}{$\begin{array}{l}\text { Poticanje interesa i likovnog izražavanja kroz } \\
\text { razgovor o nečemu što su djeca spontano vidjela } \\
\text { i doživjela prije kraćeg ili duljeg vremena. }\end{array}$} & GIM & 62 & 87,05 & \multirow{3}{*}{6,928} & \multirow{3}{*}{0,031} \\
\hline & SSŠ & 89 & 69,16 & & \\
\hline & UMSŠ & 2 & 81,50 & & \\
\hline \multirow{3}{*}{$\begin{array}{l}\text { Ilustriranje različitih priča i pjesama, } \\
\text { zamišljenih događaja, događaja iz prošlosti i } \\
\text { budućnosti. }\end{array}$} & GIM & 62 & 75,43 & \multirow{3}{*}{2,187} & \multirow{3}{*}{0,335} \\
\hline & SSŠ & 89 & 77,14 & & \\
\hline & UMSŠ & 2 & 119,50 & & \\
\hline \multirow{3}{*}{$\begin{array}{l}\text { Zamišljanje nevizualnog (glazba, osjetila, } \\
\text { osjećaji) kao poticaja za likovno izražavanje. }\end{array}$} & GIM & 62 & 78,06 & \multirow{3}{*}{0,359} & \multirow{3}{*}{0,836} \\
\hline & SSŠ & 89 & 75,92 & & \\
\hline & UMSŠ & 2 & 92,00 & & \\
\hline \multirow{3}{*}{ Igre s likovnim materijalima. } & GIM & 62 & 86,39 & \multirow{3}{*}{5,494} & \multirow{3}{*}{0,064} \\
\hline & SSŠ & 89 & 70,30 & & \\
\hline & UMSŠ & 2 & 84,25 & & \\
\hline \multirow{3}{*}{$\begin{array}{l}\text { Stvaralačke igre vezane uz djetetov doživljaj } \\
\text { likovno-umjetničkog djela. }\end{array}$} & GIM & 62 & 74,05 & \multirow{3}{*}{1,031} & \multirow{3}{*}{0,597} \\
\hline & SSŠ & 89 & 78,56 & & \\
\hline & UMSŠ & 2 & 99,25 & & \\
\hline \multirow{3}{*}{$\begin{array}{l}\text { Razvijanje verbalnih kompetencija kod djece } \\
\text { kroz razgovor o likovno-umjetničkom djelu. }\end{array}$} & GIM & 62 & 83,27 & \multirow{3}{*}{2,359} & \multirow{3}{*}{0,307} \\
\hline & SSŠ & 89 & 72,01 & & \\
\hline & UMSŠ & 2 & 78,00 & & \\
\hline \multirow{3}{*}{$\begin{array}{l}\text { Likovne aktivnosti koje su integrirane sa drugim } \\
\text { sadržajima RPOO. }\end{array}$} & GIM & 62 & 80,14 & \multirow{3}{*}{0,739} & \multirow{3}{*}{0,691} \\
\hline & SSŠ & 89 & 74,62 & & \\
\hline & UMSŠ & 2 & 82,75 & & \\
\hline \multirow{3}{*}{$\begin{array}{l}\text { Projekte likovnog stvaralaštva (dublje } \\
\text { pristupanje temi) koji traju duže vremensko } \\
\text { razdoblje. }\end{array}$} & GIM & 62 & 76,04 & & \\
\hline & SSŠ & 89 & 77,55 & 4,882 & 0,087 \\
\hline & UMSŠ & 2 & 82,25 & & \\
\hline Aktivnosti iz područja suvremene umjetnosti, & GIM & 62 & 70,33 & & \\
\hline performans, landa art, konceptualna & SSŠ & 89 & 76,08 & 1,135 & 0,567 \\
\hline umjetnost... & UMSŠ & 2 & 54,75 & & \\
\hline
\end{tabular}

LEGENDA: GIM = gimnazija, SSŠ = srednja strukovna škola, UMSŠ = umjetnička srednja škola, $\mathrm{R}$ = prosjek rangova, $\mathrm{K}-\mathrm{W}$ test = Kruskal-Wallisov test.

\section{Zaključak}

Svrha ovog istraživanja bila je analizirati samoprocjenu profesionalnih kompetencija u umjetničkom području (likovnom i glazbenom) kod studenata treće godine studija RPOO na Učiteljskom fakultetu Sveučilišta u Mariboru i Učiteljskom fakultetu Sveučilišta u Zagrebu. 
Zanimalo nas je koliko vrsta srednjoškolskog obrazovanja utječe na razinu samoprocjene profesionalnih kompetencija u umjetničkom području. Ispitane kompetencije grupirane su unutar kompozitnih varijabli: provođenje glazbenih aktivnosti, provođenje likovnih aktivnosti, provođenje glazbeno-stvaralačkih aktivnosti, provođenje likovno-stvaralačkih aktivnosti. Na temelju dobivenih rezultata možemo zaključiti da kod provođenja glazbenih aktivnosti studenti koji su završili gimnaziju imaju veću širinu znanja iz različitih područja te se osjećaju kompetentnijima u njihovu provođenju, za razliku od studenata koji su završili srednje umjetničko obrazovanje, gdje uža specijalnost, primjerice sviranje nekog instrumenta ili slično, može biti prepreka. Do sličnih rezultata došli su i drugi autori koji ističu da znanja iz različitih područja mogu poticati inspiraciju i istraživanje neobičnih pristupa. ${ }^{32}$ Kod provođenja likovno-umjetničkih aktivnosti rezultati pokazuju da studenti koji su prethodno završili umjetničko srednjoškolsko obrazovanje više koriste različite likovne tehnike u svom radu, te se bolje procjenjuju u provođenju projekata likovnog stvaralaštva, a studenti koji su završili gimnaziju osjećaju se kompetentnijima u planiranju likovnih aktivnosti i poticanju interesa kod djece da se likovno izraze. U dobivenim podacima se uočava neposredan rezultat inicijalnog obrazovanja na razvijanje osjećaja kompetentnosti kod studenata za vođenje likovno-stvaralačkih aktivnosti koje se razvija iskustvom rada u praksi. ${ }^{33}$ Važno je napomenuti da treba biti pažljiv s generalizacijama navedenih rezultata zbog neravnomjerne distribucije ispitanika po grupama: gimnazija, srednja strukovna škola i umjetnička srednja škola.

Polazeći od stajališta da je djetetovo rano i predškolsko doba ključno razdoblje za razvoj djetetove kreativnosti, odnosno zlatno doba njegova stvaralaštva, ${ }^{34}$ od odgojitelja se očekuju profesionalne kompetencije koje će mu omogućiti da pruži poticaj razvoju djetetovih kreativnih potencijala. Razvijen senzibilitet i interes odgojitelja za pojedinu vrstu umjetnosti utječe na češće provođenje stvaralačkih aktivnosti u odgojno-obrazovnoj praksi. ${ }^{35}$ Stoga je zadaća visokoškolskog obrazovanja da osposobi buduće odgojitelje koji će kompetentno poticati djetetov kreativan potencijal i prihvatiti to kao poslanje i cilj za dobrobit djeteta i cjelokupnog društva.

\footnotetext{
${ }^{32}$ Usp. Birss, nav. dj.

${ }^{33}$ Usp. Bae, nav. dj.; Gibson, nav. dj.

${ }^{34}$ Usp. Vlad Petre GLAVEANU, How are we creative together? Comparing sociocognitive and sociocultural answers, Theory \& psychology, 21 (2011) 4, 473-492.

${ }^{35}$ Usp. Bleed, nav. dj.; Hallam, nav. dj.
} 
Jerneja Herzog* - Blaženka Bačlija Sušić**** - Marijana Županić Benić****

Pre-service early childhood and preschool education teachers' self-assessment of competences in visual arts and music

\section{Summary}

Visual arts and music facilitate emotional, cognitive, social, and psychomotor development in early childhood, and therefore, preschool teachers need to develop a certain level of competence to engage children in the arts. Hence, the purpose of this study was to gain insight into pre-service early childhood and preschool education teachers' self-assessed teaching competences in the arts. Students enrolled in the third year of Early Childhood and Preschool Education study programme at the Faculty of Teacher Education, University of Zagreb and at the Faculty of Education, University of Maribor, were asked to participate in this study. The participants who graduated from grammar schools evaluated their teaching competences in music with a higher grade than the participants who graduated from secondary art schools. The participants who graduated from grammar schools were also more likely to report higher competence for planning visual arts activities, whereas the participants who graduated from secondary art schools were more likely to report higher competence in conducting visual art activities.

Key words: arts, early childhood and preschool education, teaching competences.

(na engl. prev. Alenka Mikulec)

* Jerneja Herzog, PhD, Assist. Prof., Faculty of Education, University of Maribor; Address: Koroška cesta 160, SI-2000 Maribor, Slovenia; E-mail: jerneja.herzog@um.si.

* Blaženka Bačlija Sušić, PhD, Faculty of Teacher Education, University of Zagreb; Address: Savska 77, HR-Zagreb, Croatia; E-mail: marijana.zbenic@ufzg.hr.

***: Marijana Županić Benić, PhD, Assist. Prof., Faculty of Teacher Education, University of Zagreb; Address: Savska 77, HR-10000 Zagreb, Croatia; E-mail: blazenka.baclijasusic@ufzg.hr. 